394. 乾式現像方式レーザー・イメージャ

（3M DryView）の性能と酶床評価

\title{
Clinical Evaluation of 3M DryView System
}

\begin{tabular}{|c|c|c|c|}
\hline 住友スリ一エム (株 & 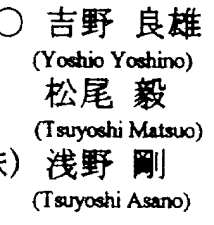 & $\begin{array}{c}\text { 速水 昭雄 } \\
\text { (Akio Hayami) } \\
\text { 有驾 政夫 } \\
\text { (Masso Ariga) } \\
\text { 佐藤 文彦 } \\
\text { (Fumithiko Satou) }\end{array}$ & $\begin{array}{c}\text { 矢野 昌男 } \\
\text { (Masto Yano) } \\
\text { 香山芳之 } \\
\text { (Yoshiyuki Hatakeyama) } \\
\text { 三枝 紀雄 } \\
\text { (Norio Secgusa) }\end{array}$ \\
\hline
\end{tabular}

\section{【目的】}

従来の湿式現像方式に対して、今回住友スリーエム社から発売された鞋式レーザー・イメージャ(DryViev)

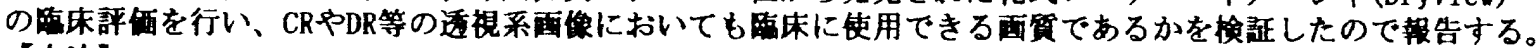
【方法】

1. 各モダリティ(CR・DR・CT)別の最道港度階調を检郡した。

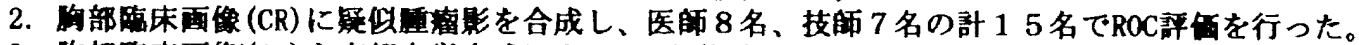

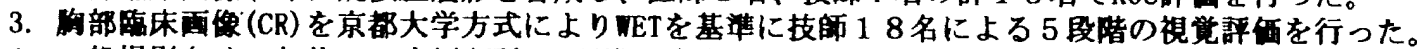

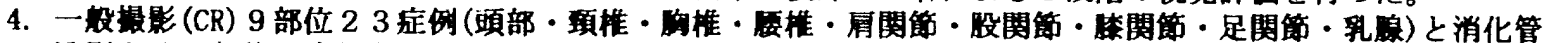

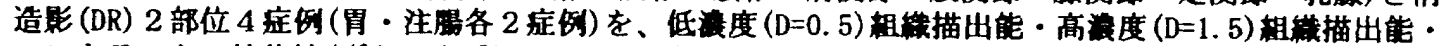

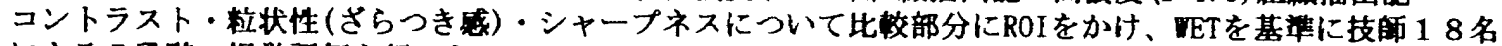
による 5 段陼の視覚䛨俩を行った。

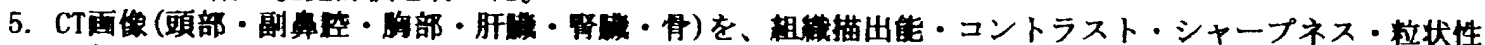

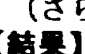

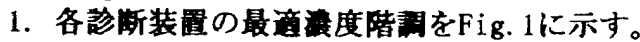

2. 部のROC壁(Fig. 2) では、Az值:DryView $=0.851 、$ TET $=0.860$ 最大情報伀達皇:DryView=0.27、WET=0.24（bit）で殆と差がなく、 Paired-t俭定でも有意差は琶められなかった。

3. Fig.3より京都大学方式の語你では、画像マトリックスの違い

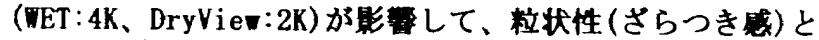
シャープネスは畔より悪かったが、合語点は DryView=56. 3、VET=56.0で同等であった。

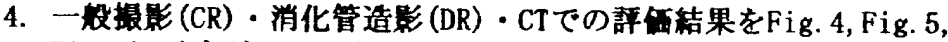
Fig. 6に示すが、コントラスト・シャーブネス柆状性 (ざらつき感) 組維描出能に殆ど差を琶めなかった。

5. 色䚴(ベース)に対する印象は、好き=35、気にならない=35、 䍩い=30（奴であった。

\section{【考察】}

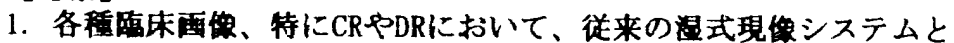
比数して同等の吾每が得られ十分满足した。

2. DryViewの特鹤である完全轨式化とコンパクトでどこにでも手怪に 設置出来ることは、公害対策・災害対策・経済的メリット及ひ 技師のメンテナンス羍務の省力化などの有用性が考えられる。

\section{【光辞】}

評佰サンプルの作成にあたり、多大な㽖力を頂きました

日本アイ・ビー・エム株式会社の输木槏、並びに

富士メディカルシステム株式会社の加藏样に厚く御礼申し上げます。

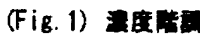

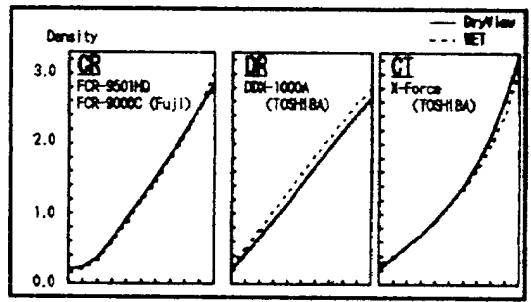

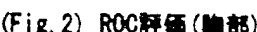

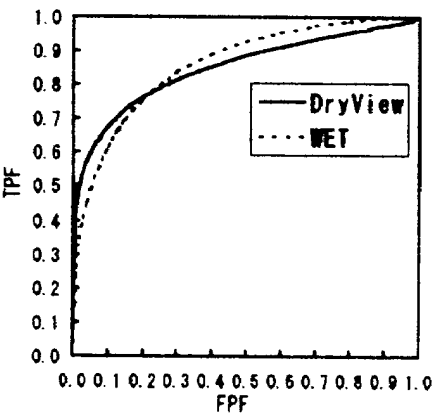

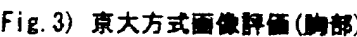

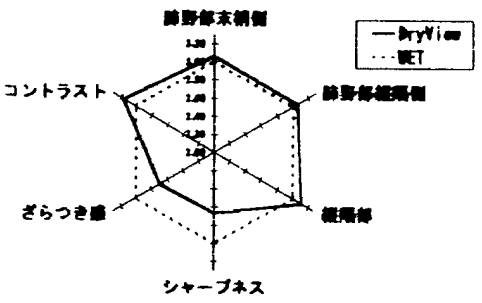

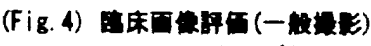

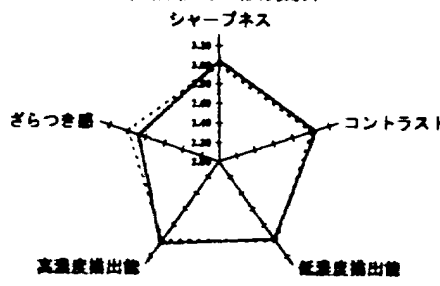

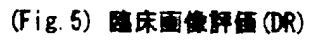

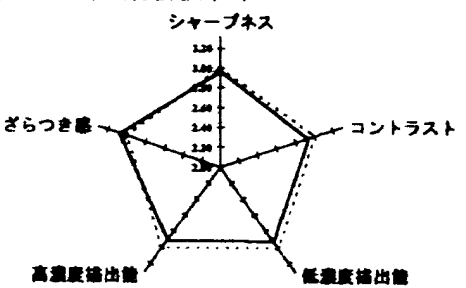

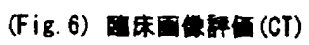

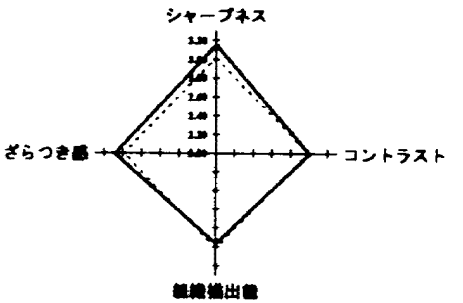

